\title{
Osmanlı Mizah Basınının Bir Temsilcisi: Latife Gazetesi (1874-1875)
}

\author{
Ersin Gözde ACER \\ Ahi Evran Üniversitesi Yüksek Lisans \\ ersingozdeacer@hotmail.com.tr \\ ORCID ID: 0000-0001-7055-7822
}

\begin{tabular}{lr} 
Araştırma Makalesi & DOI: 10.31592/aeusbed.696534 \\
\hline Geliş Tarihi: 04.03.2020 Revize Tarihi: 23.10.2020 & Kabul Tarihi: 15.02 .2021 \\
Atıf Bilgisi & \\
Acer, E. G. (2021). Osmanlı mizah basınının bir temsilcisi: Latife Gazetesi (1874-1875). Ahi Evran Üniversitesi \\
Sosyal Bilimler Enstitüsü Dergisi, 7(1), 99-117.
\end{tabular}

ÖZ

Basın, tarih araştırmaları için her zaman önemli bir çalışma alanı olmuştur. Çünkü yaşam içerisinde meydana gelen birçok önemli olayı basın kayıt altına almaktadır. Bir toplum hakkında herhangi bir bilgiye ulaşabilmek için dönemin basın yayın organlarını incelemek tarih araştırmaları için çok önemli bir kaynağı teşkil etmektedir. Mizah basınının da tarih araştırmaları için ayrı bir önemi vardır. Çünkü mizah basınının en önemli özelliği görselliğe ve hicve yer vermeleridir. Görsel unsurların ve hicvin insanları etkileme oranı çok yüksektir. Bu yüzden mizah yayın organlarının etkisi ve bu etkiye karşı doğan tepkiler çok daha fazla olmuştur. Latife gazetesi Zakarya Beykozluyan tarafından çıkarılmıştır. Bu çalışmada Latife Gazetesi’nin; 12 Ağustos 1874 (28 Cemâziyel-âhir 1291) tarihli birinci sayıdan 30 Ekim 1874 (19 Ramazan 1291) tarihi yirminci sayılar arası ile 3 Nisan 1875 (26 Safer 1292) tarihli birinci sayısından 18 Mayıs 1875 (12 Rebîül âhir 1292) tarihli yirminci sayılar arası incelenmiştir. Latife gazetesi 1870'li yıllarda yaşanan olayları mizahi bir dille gözler önüne sermiştir. Gazetede yer verilen konular; İstanbul haberleri ile belediye hizmetleri, Osmanlı'da ulaşım ve tramvay, vapur, omnibüste yaşanan sorunlar dönemin diğer gazeteleriyle aralarındaki çekişmeler, Gedikpaşa Tiyatrosu'nun yöneticisi Güllü Agop ve Osmanlı Tiyatrosundaki gelişmeler ile Osmanlı'da modadır. Bu konular hakkında genellikle alaycı bir dil kullanılmış ve daha çok hiciv ve eleştiri şeklinde yazı ve haberler gazetede yayınlanmıştır. Bu çalışmanın amacı 1874-1875 yılları arasında yayınlanan Latife gazetesi incelenerek yayınlandığı tarihte Osmanlı'da yaşanan sosyal ve ekonomik olaylara bir mizah gazetesi çerçevesinden bakarak dönemi anlamak amaçlanmıştır. Latife gazetesi mizahi bakış açısıyla özellikle İstanbul'da halkın yaşadığı pek çok sorunu dile getirmiş ve 1874-1875 yıllarında İstanbul'un gündeme 1şık tutmuştur.

Anahtar Kelimeler: Gazete, İstanbul, Latife gazetesi, ulaşım, Zakarya Beykozluyan.

\section{A Representative Of The Ottoman Press Humor: Latife Newspaper (1874-1875)}

\begin{abstract}
The press has always been an important field of study for historical research because it records many important events in life. In order to obtain any information about a society, examining the media organs of the period constitutes a very important source for historical research. The humor press has also a special importance for history research. Because the most important feature of the humor press is that they include visuality and satire. The effect of visual elements and satire is very high on people. Therefore, the effect of humor press and reactions to this effect has been much more. The Latife newspaper was published by Zakarya Beykozluyan. In this study, from the first issue of the newspaper dated August 12, 1874 (28 Cemâziyel-âhir 1291) to the twentieth issues dated October 30, 1874 (19 Ramazan 1291) and from the first issue dated April 3, 1875 (26 Safer 1292) to twentieth issue dated May 18, 1875 (12 Rebîül-âhir 1292) were examined. Latife newspaper revealed the events of the 1870s with humorous language. The general issues mentioned in the newspaper are İstanbul news, municipal services transportation in the Ottoman Empire problems in trams, steamboats and omnibus conflicts with other newspapers of the period, Güllü Agop who the director of Gedikpaşa Theater, developments in Ottoman Theater and fashion in the Ottoman Empire. A satirical language was usually used about these issues and mostly satirical and criticized articles and news have been published in the newspaper. The aim of this study is to analyze the period by looking at the social and economic events in the Ottoman Empire from the perspective of a humor newspaper, by analyzing the Latife newspaper published between 1874 and 1875. Latife newspaper, with its humorous point of view, expressed many problems especially in Istanbul and shed light on the agenda of Istanbul between 1874 and 1875.
\end{abstract}

Keywords: Newspaper, Istanbul, Latife newspaper, transportation, Zakarya Beykozluyan.

\section{Giriș}

Basın, belli zaman aralıklarıyla çıkan güncel olaylara ilişkin bilgiler içeren yayınların bütünüdür. Genellikle günlük yayınlananlara gazete; haftalık ve aylık yayınlananlara ise dergi ismi 
verilmektedir (İnuğur, 1958). Basın, tarih araştırmaları için her zaman önemli bir çalışma alanı olmuştur. Çünkü basın yaşam içerisinde gün gün meydana gelen siyasal, toplumsal, ekonomik, kültürel birçok önemli olayı kayıt altına almaktadır. Bu nedenle bir toplumun tarihteki bir kesiti ile ilgili bilgiye ulaşabilmek için dönemin basın yayın organlarını incelemek oldukça önemlidir.

Osmanlı Devleti'nde matbaayı ilk kullanan azınlıklar olmuştur. Yahudiler tarafından 1493'te İstanbul'da bir matbaa kurulmuştur. Yahudileri diğer azınlıklar izlemiştir. Sivaslı Akar tarafından 1567'de İstanbul'da bir Ermeni matbaası kurulmuştur. 1627'de Nikodemud Metasa, İngiltere'den getirttiği makinelerle ilk Rum matbaasını açmıştır (Lewis, 1993). Osmanlı Devleti'nde matbaanın geç kurulması basın-yayın organlarının yayın hayatına başlamasını doğal olarak geciktirmiştir. Osmanlı Devleti'nde matbaanın kurulmasında olduğu gibi ilk gazeteleri de azınlıklar ve yabancı devlet adamları çıkarmıştır. Fransa'daki ihtilalden sonra İstanbul'a atanan Büyükelçi Verninac'ın çıkarttığı gazete önemlidir (Çakır, 1997).

Osmanlı basın tarihi matbaanın Türkiye'ye girişinden yaklaşık bir asır sonra Mısır Valisi Kavalalı Mehmet Ali Paşa'nın yayınlattığı "Vekayi-i Mısriye" ile başlatılır (Kabacalı, 2000). Böylelikle Osmanlı'da Türklerin yayınladığı ilk gazete yayın hayatına başlamıştır. 11 Kasım 1831'de Takvim-i Vekayi bizzat Sultan II. Mahmut'un gayretleriyle çıkarılmış ve Takvimhane-i Âmire'de basılmıştır (Ertuğ, 1970). Böylece basın hızlı bir gelişim sürecine girmiştir. Takvim-i Vekayi'nin çıkarılışından yaklaşık 10 yıl sonra İngiliz asıllı bir tüccar olan William Churchill tarafindan 1840 y1lında Ceride-i Havadis, kurlmuştur (Baykal, 1990). Ceride-i Havadis, ülkemizde özel teşebbüs ile çıkarılıp kısa süre sonra kamu eline geçen ve bu şekilde yayın hayatını sürdüren bir gazete olmuştur.

Tanzimat döneminde, halkı aydınlatmak ve kamuoyu oluşturmak için birçok gazete, dergi gibi basın yayın organı çıkarılmışıı. Basın dünyasında bir canlanma yaşanmıştır. 1860'tan itibaren Osmanlı basın dünyasında yaşanan canlanmayla, ilk özel gazete de bu dönemde yayınlanmıştır. Basın tarihimizin ilk gerçek manada özel gazetesi Tercümân-1 Ahvâl'dir. İlk nüshası Agâh Efendi ve Şinasi tarafından 21 Ekim 1860'da Bahçekapı'da çıkartılmıştır (Ertuğ, 1970). Tercümân-1 Ahvâl gibi Türk gazeteciliğinin ikinci dönemine haiz olan "Tasvir-i Efkar" gazetesi ise 27 Haziran 1862'de Şinasi tarafından çıkarılmıştır (Çavdar, 2007). Gazete, haberlerin yanı sıra düşünce özgürlüğü gibi konulara da yer vermiştir.

Türk mizah basını açısından da Tanzimat döneminde çok önemli gelişmeler yaşanmıştır. Tanzimat'la birlikte kurumsal yapı ve yaygınlık kazanan gazete, dergi, vb. süreli yayınlara bu oluşum içinde sözlü kültür ve edebiyat birikimi önemli bir kaynaktır ve Tanzimat dönemine kadar Türk mizahı sözlü gelenekle özellikle fikralarla temsil edilmiştir (Apaydın, 2007). Tanzimat ile birlikte yazılı mizah unsurlarıda gelişmiştir. Tanzimat döneminin ilk hiciv örneği, Ziya Paşa'nın Zafernâme Şerhi adlı eseridir. $\mathrm{Bu}$ eserde Osmanlı şiir geleneği ile Batılı hiciv anlayışının özelliklerini görmek mümkündür. 1866'daki Girit isyanında Sadrazam Ali Paşa'nın gönderdiği donanmanın başarısız olması nedeniyle yazılan bu eser, başarısızlığı başarı gibi göklere çıkartarak ince bir şekilde yaşanan başarısızlığı alaya almıştır (Akyüz, 2017).

Osmanlı Devleti'nin ilk mizah dergisi Hovsep Vartanyan Paşa tarafından çıarılmıştır. Boşboğaz Bir Âdem adını taşıyan derginin karikatürleri de Hovsep Vartanyan tarafından çizilmiştir. Mizah dergilerinin en önemli özelliklerinden birisi görselliğe yani karikatürlere yer vermeleridir. Görsel unsurların insanları etkileme oranı çok yüksektir. Bu yüzden mizah yayın organlarının etkisi ve bu etkiye karşı doğan tepkiler çok daha fazla olmuştur. Mizah basınına daha çok Ermeni vatandaşlar öncülük etmişlerdir (Çeviker, 1986). Çalışmaya konu olan Latife mizah gazetesini de Ermeni asıllı vatandaşlardan Zakarya Beykozluyan Efendi tarafından çıkarılmıştır.

İlk Türkçe mizah gazetesi olan Diyojen, Teodor Kasap tarafından çıkarılmıştır. Türkçe olarak yayınlanmadan önce Ermenice ve Rumca olarak da yayınlanmıştır. Gazete birkaç kere kapatılmış ve yeniden açılmıştır. Bu gazetenin en önemli özelliği Türk basın tarihinde mizahın temellerini atmasıdır (Topuz, 1997). Gazete dönemin olaylarını iğneleyici bir dille eleştirmiş ve dönemin ilklerini imza atmıştır. Diyojen gazetesinden sonra, Tanzimat döneminde birçok mizah gazetesi ve dergisi 
yayınlanmıştır. Bu dergilerin bazıları; Terakki Eğlence - 1870, Asır'ın Eğlence Nüshası Âlem - 1873, Kamer - 1873, Hayal - 1873, Latife - 1874 (Çalışmanın konusu olan mizah gazetesidir.), Tiyatro 1875, Kahkaha - 1875, Geveze - 1875, Kara Sinan - 1875, Çaylak - 1879, Meddah - 1876 gibi dergi ve gazetelerdir (Çeviker, 1986). Yayıncısının Müslüman ve Türk olduğu ilk mizah dergisi ise Çaylak olmuştur. 1876 yılında Mehmet Tevfik tarafından çıarılan dergi bir sene yayınlandıktan sonra kapanmıştır (Özer, 1994).

Meşrutiyetin ilanından, I. Dünya Savaşı'na kadar İstanbul ve taşrada çıkan mizah gazetelerini belli başl1ları; Afacan -1911, Boşboğaz ile Güllâbi - 1908, Cadaloz - 1911, Dalkavuk -1908, Falaka 1911, Geveze - 1908, Hacivad-1908, Hayal-i Cedid - 1910, Karagöz - 1908, Latife -1911 (Latife adıyla 1911 yılında yayınlanan gazetedir. II. Meşrutiyet döneminde yayınlanan gazetenin başyazarı Fuad Talat'dır.1874 ve 1875 yılında yayınlanan Latife gazeteleri çalışmanın konusu olan mizah gazeteleridir.), Mir'at-1 Âlem, Nasreddin Hoca - 1908, Püsküllü Belâ - 1909, Yeni Geveze -1910, Zuhûrî - 1908 gibi dergi ve gazetelerdir (Altın, 2014).

Bu çalışmanın genel amacı, 1874-1875 yılları arasında yayınlanan Zakarya Beykozluyan tarafından çıkarılan ve bir mizah gazetesi olan Latife gazetesinin yayınlanmış sayılarını incelemektir. Böylece Osmanlı'da 1874-1875 yılları arasında yaşanan olaylara Latife aracılı̆̆ıyla ışık tutmak amaçlanmıştır. Latife gazetesinin önceden incelenmemesi ve bir mizah gazetesi olmasi sebebiyle kullandığı hiciv sanatı düşünülerek dönemi daha iyi anlamak istenmiştir. Ayrıca mizah gazetelerinin en önemli özelliği olan karikatür sanatı ve görsel içerikte dönemi anlamak için çok önemli görülmüştür. Çünkü eleştirel yaklaşımı ve alaycı yorum ile görselliğin insanlar üzerinde etkisinin çok fazla olduğu aşikardır.Bu yüzden çalışmada karikatür örnekleriyle dönemin sorunlarına yapılan vurgulara da s1kça yer verilmiştir.

Basının topluma yön verme gücü düşünüldüğünde bir de bunu eleştirel yaklaşımı, yorum ve görselliği ekleyen mizah basınının etkisi tartışmasız çok büyük olmuştur. Mizah basınını diğer basın yayın organlarından ayıran karikatür sanatıdır. Karikatürler hem görsel olması hem de içinde barındırdığı yoğun anlamlar nedeniyle önemli usurlardır. Latife gazetesinde de her sayıda karikatüre yer verilmiş ve bu karikatürlerle gündem okuyucuya aktarılmıştır.

Latife gazetesinin incelenen sayılarına Hakkı Tarık Us Kütüphanesi aracılığıyla erişilmiştir.Yayınlanan sayıların Osmanlı alfabesinden transkripsiyonu yapılmıştır.Ayrıca Arapça ve Farsça kelimelerin de Türkçe karşılıkları kullanılarak aktarılmıştır. Latife'de yer alan konular yoğunluğa ve öneme göre sıralanarak belli başlıklar altında toplanmıştır. Böylece 1874-1875 yılları arasında yaşananlara Latife'nin gözünden bakma firsatı bulunmuştur.

Sonuç olarak, Latife 1874-1875 yılları arasında özellikle İstanbul'da halkın yaşadığı pekçok sorunu gözler önüne sermiştir. İğneleyici bir dil kullanılarak yaşanan sıkıntılar ve dönemin gündemi Latife'ye konu olmuştur. Latife'den elde edilen bilgiler ile mizahi bir çerçeveden dönemin sorunlarına bakılmıştır. Latife gazetesinde siyasi olaylara çok az yer verilmiştir. Genellikle İstanbul gündemi İstanbul'da halkın yaşadığı sıkıntılar ve yaşanan ekonomik sosyal sorunlar dile getirilmiştir. 18741875 yıllarında İstanbul'da halkın yaşadığı pekçok ekonomik ve sosyal sorunun özellikle İstanbul'da ulaşımda yaşanan sıkıntıların günümüzde de benzer şekillerde yaşandığı anlaşılmaktadır.

\section{Latife Gazetesinin Teknik Özellikleri}

Latife'nin imtiyaz sahibi, Ermeni asıllı Zakarya Beykozluyan'dır. Latife gazetesinin her sayıs1 üç sütun halinde dört sayfadan oluşmuştur. Zakarya Beykozluyan, Latife ismini kullanarak 3 Nisan 1875 'te gazeteyi ikinci kez çıkarmıştır. Bu sayılar öncekilerden farklı olarak iki sütun dört sayfa şeklinde varlığını sürdürdükten sonra kapanmıştır.

Latife gazetesinin 12 Ağustos 1874 (28 Cemâziyel-âhir 1291) - 30 Ekim 1874 (19 Ramazan 1291) tarihleri arasında yayınlanan sayıların içeriğine baktığımızda genellikle birinci sayfada dönemin aktüel konularına dair uzunca bir makale yer almıştır. Ayrıca haberlere her sayıda kısa da olsa yer 
verilmiştir. Latife'de en dikkat çekici yazı dizilerinden birisi diyalog tarzı yazılardır. Yine en çok yer tutan bir diğer haber İstanbul'un çeşitli sorunlarının mizahi bir dil ile anlatılması olmuştur. Ayrıca gazetede Osmanlı Devleti'ndeki toplu ulaşım vasıtaları ve yaşanan sorunlar da genişçe yer tutmuştur. Gazetede, telgraflar, okuyucu mektupları ve son sayfalarda ilanlar yer almıştır. Şiir ve fikra gibi edebi yazılar da vardır. Latife gazetesinin en önemli uğraş alanı olan bir diğer konuda dönemin gazeteleriyle yaşanan çekişmeleridir. Bir diğer önemli konu Osmanlı Tiyatrosu ile Gedikpaşa Tiyatrosu'nun sahibi ve yöneticisi Güllü Agop'tur.

Latife gazetesinin 3 Nisan 1875 (26 Safer 1292) - 18 Mayls 1875 (12 Rebîül-âhir 1292) tarihleri arasındaki nüshaları ise iki sütun halinde yayınlandığı için içerik yoğunluğu daha azdır. Burada en dikkat çeken konu 1874 yılında yayınlanan sayılarda dört sayfa numarası ile çıkan gazete diğer sayılarda devam etmiş ve ikinci sayının ilk sayfası beş sayfa numarası ile başlamıştır. Aralıksız sayfalar bu şekilde devam etmiştir. 1874 yılında yayınlanan sayılarla içerik genelde aynıdır. Yine haberler, diyaloglar, telgraflar, ilanlar, mektuplar, edebi türler genişçe yer tutmuştur. Farklı olarak tefrika bağlamında Zakarya Beykozluyan imzasıyla yayınlanan Elenko Hikâyesi dikkat çekmektedir.

\section{Latife Gazetesinin İncelenmesi}

\section{Yurtiçi Haberleri}

Latife gazetesinde yurtiçi haberler genellikle "Havâdis-i Dâhiliye" adıyla verilmiştir ve geçen haberler hiciv diliyle aktarılmıştır. Daha çok İstanbul haberleri, ulaşım sorunu ve ekonomik sıkıntılar hakkında kısa haberler bu başlık altında yerini almıştır.

"Havâdis-i Dâhiliye" başlığıyla ikinci sayıda yer alan haber şu şekildedir; "Bu sabah köprübaşına sıra ile katarlanmış olan kupa arabalarının seyisleri açlıktan türkü çağırmakta ve hayvanların ise yorgunluktan uyumakta oldukları işitilmiştir" (Latife, 15 Ağustos 1874, s. 2). Köprübaşı'nda görülen arabacıların ve havyanların aç ve bitkin olduğu İstanbul ulaşımında kullanılan atlı arabaların ve omnibüs arabalarının durumu anlatılmıştır.

\section{Diyaloglar}

Latife'de "Muhâvere" başlığı altında diyaloglar yer almıştır. Bunlar, giyim-kuşam, zenginlikzüğürtlük, dönem gazeteleri arasındaki atışmalar, İstanbul'un sorunları, Osmanlı tiyatrosu, ulaşım gibi konulara aittir. Ayrıca diyaloglar çoğunlukla iki kadın arasında, vapur yolcusu ile biletçi arasında, iki yolcu arasında, doktor ve hastası arasında, sokakta karşılaşan iki dost arasında veya dönem gazeteleri arasında gibi çeşitli şekillerde kurgulanmıştır. Gazetenin önemli eleştiri konularını işlemiş olan diyaloglar bölümündeki yazılar dönemin şartlarını anlamak için önemli bir yere sahiptir. Bu bölümde hicivli bir mizah dili kullanılmıştır.

Gazetede yer alan diyaloglardan birine örnek vermek gerekirse, zabita memuru ile esnaf arasında geçen diyalog şu şekilde gazetenin birinci sayısında yerini almıştır;

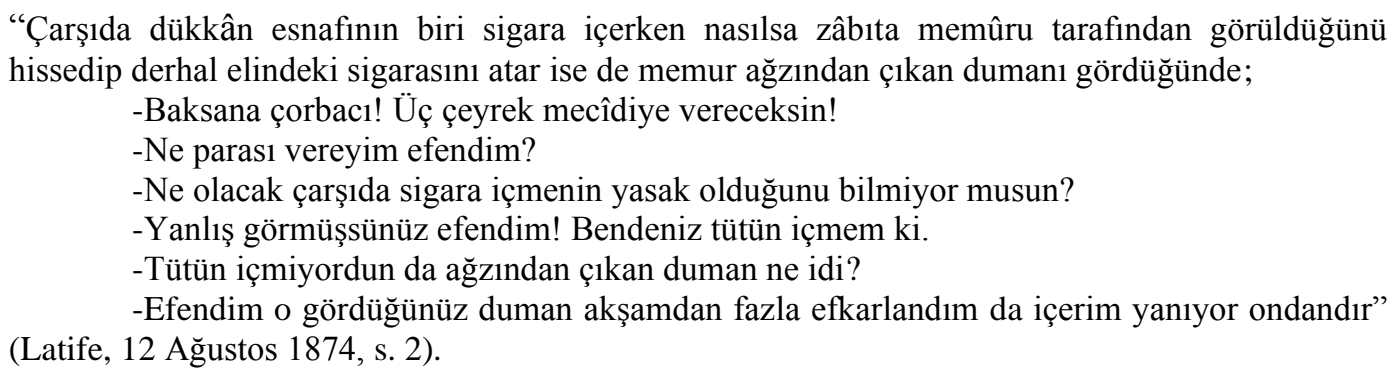

$\mathrm{Bu}$ diyalogda o dönemde dükkânda sigara içme yasağının uygulandığı anlaşılmaktadır. Zabıta memuru ile esnafın arasında yaşanan diyalog mizahi bir şekilde yayınlanmıştır. 


\section{Telgraflar}

“Telgraf" başlığı altında çeşitli semtlerden çekilen gerçek veyahut hayali olduğu anlaşılan telgraflara yer verilmiştir. Bu telgraflarda genelde çekildiği yerin bir problemi hiciv eleştiri karışımı bir dille aktarılmıştır. Telgraflarda Latife gazetesinin eleştirdiği konulara dair önemli bilgiler almak mümkündür. Gazetede yer alan telgraflar genellikle belli yerlerden çekilmiş ve çekildiği yere göre gazetede belli başlık ile yayınlanmıştır. Galata ve Galata tünelinden, Eminönü'nden, Gedikpaşa Tiyatrosu'ndan, Camlı Han'dan, Köprübaşı'ndan, Çenberlitaş’tan, Yeni Cami'den, Ahiret'ten gibi başlıkları ile yer adları verilerek çekilen telgraflar yayınlanmıştır.

Eminönü’nden başlı̆ğ ile yayınlanan telgraf şu şekildedir; "Eminönü: Köprübaşı arabaların izdihâmından dolayı hâlâ giriş çıkışları kapalı durumdadır. Bakkallar piyasasında Hulâsatü'l-Efkâr'ın her okkasına on para zam olunmuştur" (Latife, 12 Ağustos 1874, s. 3). Köprübaşı'ndan İstanbul'un pek çok yerine hareket eden arabaların kapalı yollar nedeniyle kullanılamadığı aktarılmıştır. Anlaşılan İstanbul'un günümüzde de en önemli sorunu olan ulaşım sorunu eskiden beri devam etmektedir. Ayrıca Hulasatü'l Efkâr Gazetesi'ne yapılan zam telgrafta yer almıştır. Pul vergisi nedeniyle pek çok gazete ücretine zam yapma yoluna başvurmuş ve gazete ücretleri zamlanmıştır.

\section{İlanlar}

Gazetede yer alan önemli bir başka bölümde "İlânât veya İlan" başlığı altında yer almıştır. Yayınlanan her sayıda en az bir tane ilana yer verilmiştir. Bu ilanlar çoğu sayıda tekrarlanmıştır ve daha çok gazetenin son sayfasında yerini almıştır. Gazetede 1874 yılında yer alan sayılarda ilanlar genişçe yer tutarken, kapandıktan sonra 1875 yılında tekrar çıkan sayılarda ise daha az ilana yer verilmiştir.

Latife'de edebiyat, kültür ve sanat ilanları çokça yerini almıştır. Bu durum iki türlü yorumlanabilir kültür sanat faaliyetlerine ya talep az olduğu için ilan verilerek talep arttırma amaçlanmış ya da o dönemlerde kültür sanat faaliyetlerine ilgi çok fazla olduğu için bu tarz ilanlara çokça gazetede yer verilmiştir. Bu ilanlardan birine örnek vermek gerekirse; "Mâcerâ-i Aşk ve Kara Tâlih nam fâcialar ve Fitne-i Şükrü nam tiyatro ve yeni basılan Rodos'un Hâce-i Osmânî ve Şerh-i Şafaknâme ve her cins târihler, mekteb ve tiyatro kitapları Köprübaşı'nda bulunan kitapçı barakasında satılmaktadır" (Latife, 9 Ekim 1874, s. 4). Köprübaşı'nda bulunan kitapçının ilanında farklı konulardaki kitapların satıldığına dair bilgi verilmektedir.

Latife'de yer alan iş yeri ve alım satım ilanlarında ise; dördüncü sayıda yer alan ilan şu şekildedir; "Süleymâniye'de düğmeciler içinde iki bin arşın arsa üzerine kurulu harem ve selamlık yirmi odalı ve iki bin zirâ bahçe ile içinde hamamı ile altı hayvanlık ahırı bulunan ve Marmara ve Karadeniz'i mükemmel gören konak diğer müştemilâtıyla beraber satılıktır" (Latife, 22 Ağustos 1874, s. 4). Süleymaniye'de satılık veya kiraya verilecek mülk ile ilgili ilan gazetede yer almıştır. İlanda iki bin metre arsa üzerine kurulu harem ve selamlık şeklinde yirmi odalı ve bahçe içinde hamamı ile büyük mahzeni ve birkaç yerde lezzetli suyu, altı hayvanlık ahırı gibi detaylı bir şekilde taşımaz mülkün bütün özelliklerine ilanda yer verilmiştir.

Sağlıkla ilgili ilanlar da Latife'nin sütunlarında yerini almıştır. Mesela;"Eğrikapı içinde Avcı Bey Cami-i Şeriffi karşısında 21 numaralı evde hunnak (boğaz hastalığı) hastalığına mübtelâ olanlara ücretsiz nefes edilmekte olduğu ve müracaat edenlerin şifa buldukları ilan olunur" (Latife, 5 Eylül 1874, s. 4). Anlaşılacağı üzere geleneksel tedavi yöntemlerin uygulandığı yer hakkındaki ilan okuyucuya aktarılmıştır.

\section{Mektuplar}

"Varaka" adıyla yayınlanan okuyucu mektupları ve Latife'nin bunlara cevapları gazeteye ayrı bir çeşitlilik katmıştır. Bu yolla genellikle gazeteye gelen mektuplara cevap verilmiş ve mektuplar gazetede cevaplarıyla birlikte ya aynı sayıda ya da bir sonraki sayıda yayınlanmıştır. 

ile ilgilidir;

Latife'ye gelen okuyucu mektuplarından beşinci sayıda yer alan mektup da dönem gazeteleri

\begin{abstract}
"Biz değerli okuyucular Hazreti Cerîde-i Havâdis, Basiret, Terakki Mecmua-i Lâ Türki bilmem ne bilmem ne birçok gazeteleri ara sıra okuyup da can sıkıntısı olduğunda Hayal ve Tiyatro eğlence gazetelerini -kuruşu yazılmakla- alır okur ve iyi kötü eğlenirdik. Mümkün mertebe can sıkıntımız da def olurdu! Bir de Latîfe isimli bir gazete teşrif buyurdu. Hoş geldiniz, safa geldiniz! Lâkin şimdi biz fikrî bir çımaza girdik. $O$ da şudur ki: Eğleneceğim diyerek üç kuruş verip de üçünüzü birden almak tasarrufa riayetsizlik demek olacağından acabâ eğlenmeğe lüzûm kalmamak üzeri diğer gazeteleri mi almayalım, yoksa varlığı çok gerekli sizler için kura atarak ve istihâreye yatarak mı paramızı harcayalım? İknâ edici cevap isteriz. İmzâ: Bir mîrâsyedi”' (Latife, 26 Ağustos 1874, s. 2).
\end{abstract}

Mektupta yayın hayatına yeni başlayan Latife gazetesi ile diğer mizah gazeteleri Hayal ve Tiyatro'yu almak isteyip arada kalan okuyucunun mektubuna gazetede yer verilmiştir. Okuyucu mektupta Cerîde-i Havâdis, Basiret, Terakki, Mecmua-i Lâ Türkî gibi gazetelerin sıkıcı olduğu Hayal ve Tiyatro Gazetelerinin eğlenceli olduğunu bu gazetelere eklenen Latife'yi almak istediği ancak bu seferde ekonomik sıkıntı yaşayacağını dile getirmiştir. Seçim yapmak için kura çekmeyi veya istihareye yatmayı düşündüğünü anlatmıştır.

\title{
Tefrikalar (Elenko Hikâyesi)
}

1875 yılındaki sayılarda yer alan Elenko Hikâyesi tefrika bağlamında önemli bir yere sahiptir. Elenko Hikâyesi Zakarya Beykozluyan imzasıyla yayınlanmış ve her bölümde ayrı bir resimle okuyucuya sunulmuştur. Süreli yayınlarda ardı ardına yayımlanan ve birbirini tamamlayan bölümlerden oluşan yazı dizisine tefrika denilmektedir. Gazetede Zakarya Beykozluyan imzasıyla yayınlanan "Elenko Hikâyesi" tefrika bağlamında dikkat çekmektedir. Elenko Hikâyesi 1875 tarihli gazetenin ilk sayısında "Beyoğlu viranelerinde bir baraka" cümlesiyle başlayıp diğer sayılarda da devam etmiştir. Bölümler şeklinde diğer gazete sayılarında Zakarya Beykozluyan imzasıyla yayınlanmıştır. Hikâye, Elenko'nun başından geçenler üzerine kurulmuştur. Elenko hikâyesi başlıklı tefrikanın başkarakterleri 16 yaşlarındaki ve güzelliği ile nam sürmüş Elenko ve yaşlı teyzesi Marigo'dur. Ayrıca Elenko'nun diğer teyzesi Mimika, Elenko ile evlenmek isteyen Yanko Bey ve dayısı Anastaş diğer karakterlerdir.

Latife gazetesinde yer alan tefrikada gazetenin ilk sayısında yer alan ve ilk bölümünde anlatılan hikâye şu şekilde başlamaktadır; "Beyoğlu virânelerinde bir baraka. Bundan birkaç sene önce bir gece saat üç, üç buçuk sıralarında hava açık mehtap yeryüzünü aydınlatırken Beyoğlu'nda bir sene önce yangın çıkmış bir yerde yeniden inşa olunmuş olan bazı yüksek kargir binaların arasında tam manzaralı iki penceresi olan eski tahtalardan yapılmış ufacık bir baraka içinde ihtiyar bir kadın ile bir de tahmînen on altı on yedi yaşlarında bir kız çocuğu konuşmakta idiler" (Latife, 3 Nisan 1875, s. 3). İfadeleriyle hikâye devam etmektedir. Elenko Hikâyesi dönemin sosyal ve kültürel şartlarını anlamak adına önemli bir edebi üründür.

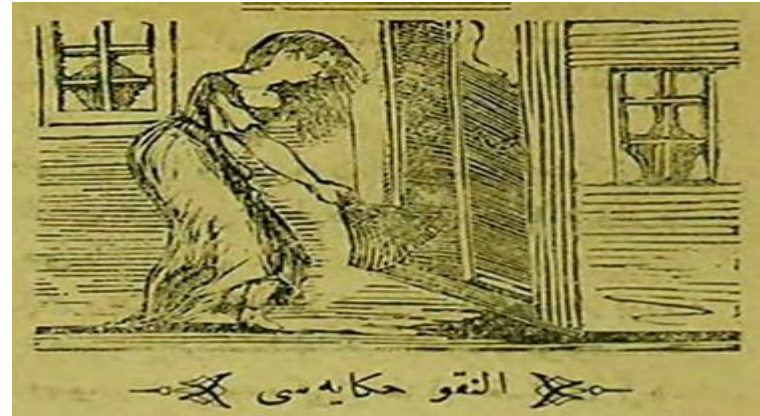

Resim 1. Elenko Hikâyesi’nin Tasvir Edildiği Karikatür 
1875 yılında yayınlanan hikâyenin ikinci bölümü ikinci sayıda yer alan karikatür bu şekilde çizilmiştir. Karikatür altı yazıda; "Elenko Hikâyesi" yazmaktadır (Latife, 6 Nisan 1875, s. 7). Tefrikanın diğer bölümlerinde de hikâye farklı karikatürlerle Latife'de yayınlanmıştır.

\section{Makaleler}

Latife gazetesinin genellikle ilk sayfalarında yer alan ve bir mizah gazetesi için çok fazla bilgi içeren yazılar dikkat çekmektedir. Bunlardan birine örnek vermek gerekirse; Latife gazetesinde yer alan ve birkaç sayıda devam eden milletlerin durumu başlıklı yazıda Yahudi, Japon ve Çingene milletlerini hem fiziksel, hem kültürel, hem de toplumsal durumları hakkında hiciv ve eleştiri dozu yüksek ifadelere yer verilmiştir. Yazıda dikkat çeken bir başka unsur ise verilen bilgilerin detaylı ve bilgi düzeyinin yüksek olmasıdır. Bu yazıyı yazarken okuyan kişinin her yönüyle Yahudi milletini tanıması amaçlanmıştır. Fakat kullanılan dil ve seçilen bazı kelimeler ağırdır. Verdiği bilgiler dikkate alındığında bir mizah gazetesi için içerik kayda değerdir. Ahvâl-i Milel başlıklı yazıdan başka Ahvâl-i Âlem, Keşif, Devir ve İdâre, Harabâtîlik, Zuhûrât, Dilencilik ve Dilencilik Hocası gibi yazılar da Latife'de yer almıştır. şekildedir;

Milletlerin durumu "Ahvâl-i Milel” başlıklı yazıda Yahudilerin anlatıldığı bölüm şu

"Eski milletlerden olması nedeniyle kendileri eskilikle iftihar ve kanaatle meşhurdur. Milletlerinin eski olmasından dolayı alış veriş ticâret ve sanatları dâima eski şeyler ile olduğu gibi yumurtayı kokutup ve eti çürütüp yiyerek ve rakı ve şarabın fiçı dibinde kalmışını içerek yiyecek ve içeceklerinde de eskiyi itibar ederler. Fakirlerinin yanında en nefis yiyecek palamut ve altıparmak başlarından paça olup zengincelerinin en muteber yemeği karaman koyunu kuyruğundan külbastıdır. Adı geçen millet yiyecek ve içecek ve diğer hususlar gibi giyecek konusunda da eski giymek âdetleri olup yalnız özel günleri olan Cumartesi günü giyinmek üzere her birinin haline göre birer kat temizce elbisesi ve Cumartesi kavukları vardır. Ve bunlardan başka özel günlerindeki âyine güneşin batışında başladıkları için günün de eskisi kendileri için muteberdir" (Latife, 24 Ekim 1874, s. 1).

Milletlerin durumu adlı birkaç sayıda yayınlanan yazıda Yahudi milleti hakkında çok detaylı bilgiler verilmiştir. Yaşayışları, kültürleri, dilleri, fiziksel özelikleri erkek bayan olarak ayrıntılı bir şekilde dile getirilmiştir. Ayrıca Japon milleti ve Çingeneler hakkındada detaylı bilgiler veren yazılar da yer almaktadir.

\section{Karikatürler}

Karikatürler mizah gazetelerinin değişmez materyallerindendir. $\mathrm{Bu}$ bağlamda Latife'nin hemen her sayısında karikatürlere rastlamak mümkündür. Zaten mizah gazetesini diğer gazetelerden ayıran da karikatür sanatıdır. Ayrıca görsel materyal ile sağlanan etkinin daha fazla olduğu bilimsel olarak kanıtlanmıştır. Bu sebeple karikatürler gazetedeki en önemli unsurlardır. Ancak karikatürleri tam anlamıyla anlayabilmek için dönemin siyasi ve sosyal olayları ile devlet adamlarını iyi bilmek gerekmektedir. Ayrıca gazetede karikatür çizimlerinin ve espri anlayışının zayıf olduğu görülmektedir. Fakat bu noktada zamanın tarihsel koşulları düşünmek ve anakronizm yapma yanlışına düşmemek gerekmektedir. Latife'de yer alan karikatürler dönemi görsel olarak sunması ve özetlemesi açısından çok önemli bir yere sahiptir. 


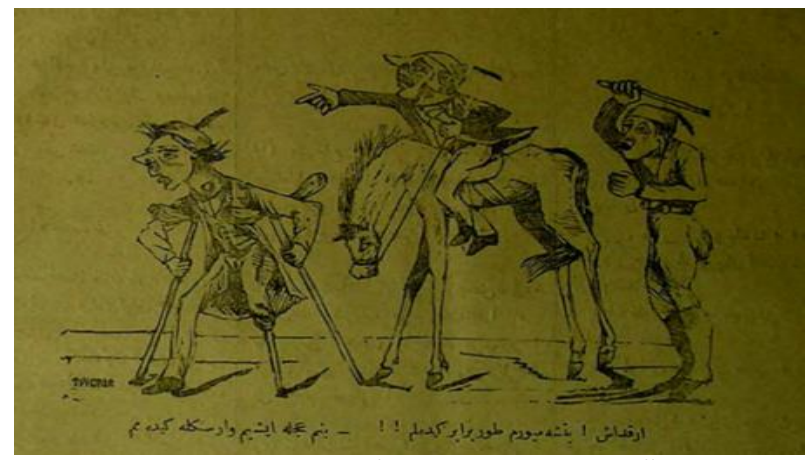

Resim 2. Tınghır İmzalı Karikatür Örneği

Dönemin ünlü karikatüristi Tınghır tarafından imzalanan karikatürlere Latife'de çok az yer verilmiştir. Sol alt köşede Tınghır imzası bulunan bu karikatür Latife'nin altıncı sayıda yerini almıştır. Karikatür altı diyalog şu şekildedir;

"Yürümek istemeyen zayıf bir atın üzerindeki adam:

-Arkadaş yetişemiyorum, dur beraber gidelim!

Koltuk değnekleriyle önde yürüyen adam:

-Benim acele işim var, seninle gidemem” (Latife, 29 Ağustos 1874, s. 4).

\section{İstanbul Haberleri}

\section{İstanbul Belediye İşleri}

Osmanlı Devleti sınırları genişleyip, içinde yaşayan nüfus artıkça başkentte yaşayan insan sayısı da artmış doğal olarak belediye işlerindeki düzen ve işleyiş haber konularının başında gelmiştir. Latife de mizahi bir dille belediyenin işleyişini ve faaliyetlerini eleştirmiştir. Mesela; "Eski adet olduğu üzere yangın çıktığında atılan toplar için vukubulan masraf bu senenin bütçesinde bir hayli artmış olduğundan bundan böyle bir yerde yangın çıkarsa sigortacılar atacakmış" (Latife, 19 Ağustos 1874, s. 1). Çıkan yangınları haber vermek için kullanılan topların masrafiyla ilgili haber gazetede yer almıştır. O zamanlarda İstanbul'da evlerin birbirine çok yakın olması nedeniyle yangının hızla yayılmasını ve can kaybını önleyebilmek amacıyla kullanılan top sesleri dönemin şartlarını çok güzel bir şekilde özetlemektedir. Günümüzde halen Ramazan aylarında kullanılan iftar toplarıyla mantık aynıdır. Burada yangın tehlikesini insanlara duyurmak can ve mal kaybını azaltmak amaçlanmıştır.

\section{İstanbul Terkos Gölü}

İstanbul'un Avrupa yakasında bulunan Terkos Gölü'nün tarihi oldukça eskilere dayanmaktadır. Bir ara Cenevizliler tarafından farklı amaçlarla kullanılan göl, 19. yüzyıla gelindiğinde Avrupalıların yardımıyla bazı tesisler inşa edilerek İstanbul'un su ihtiyacını karşılamak amacıyla kullanılmaya başlanmıştır. İstanbul için böylesi büyük öneme sahip Terkos Gölü, Latife'de sıklıkla yerini almıştır. Gazete o dönemde yaşanan su sıkıntısını ve susuzluk çokça eleştirmiştir.

Yaşanan su sıkıntısını ve susuzluk ile ilgili Terkos Gölü'nden başlı̆ğ altında çekilen telgraf şu şekildedir; "Bazı çeşme ve sebillerin evvel akan sularının nerelere aktıklarını tahkik ederek su yolcular ile kuyu kuvvetli bir sözleşme yapmadıkça bir damla su veremeyeceğini Terkos Gölü kadıya beyan etmiş̧tir" (Latife, 27 Ekim 1874, s. 1). Terkos suyunun boşa harcanması eleştirilerek bu durumun çekilen su sıkıntısını artıracağı Terkos Gölü'nün ağzından dile getirilmiştir. Latife'ye gelen telgrafta da yaşanan su sıkıntısı ve susuzluk kişileştirme sanatı kullanılarak aktarılmıştır. 


\section{Tekel İdaresi}

Osmanlı Devleti'nin en önemli gelir kaynaklarından biri olan Tekel İdaresi Latife gazetesinin zaman zaman eleştiri oklarını üzerine çekmiştir. Bu eleştirilerin temelinde ürünlerin kalitesizliği başı çekmiştir. Bu bağlamda sigaraların kalitesizliği ve paket içinden çıkan yabancı maddeler Latife'nin haberleri arasında yerini almıştır.

Bu konu ile ilgili dördüncü sayıda yer alan haber şu şekildedir; "Tütün paketlerinin bazılarının içinde talaş ve başka şeylerin çıkması üzerine tekel idaresinin tütün bedeli için aldığı paraları da kapalı paket içinde almaya karar vereceği haber alınmıştır" (Latife, 10 Nisan 1875, s. 13). Anlaşılacağı üzere sigaraların kalitesizliğine vurgu yapılmış olup hatta biraz da mübalağa yapılarak ödenen ücretinde kapalı paketle verilmesi gerektiği böylece para yerine sigaralardan çıkan tütün dışı maddeler ile ödeme yapılacağı alaycı bir dille vurgulanmıştır. Bu tür haberlerin Latife'de çok fazla yer alması Tekel İdaresinde yaşanan sıkıntının büyüklüğünü ortaya sermektedir.

\section{İstanbul Sokak Lambaları}

İstanbul sokaklarını aydınlatmak için bazı sokaklara lambalar yerleştirilmiştir. Sokak lambaları gaz kullanılarak aydınlatmaktadır. Lambaların yanması için öncelikle gaz gereklidir. Ayrıca bu lambaların gece yakılıp gündüz söndürülmesi gerekli olduğundan bunları yapacak görevliler de gerekliydi. Zamanın şartları gereği hem lambalar için gaz bulabilmek ve sokak lambalarıyla ilgilenecek görevli tayin etmek zor olmuştur. Bu yüzden birçok lamba düzenli yanmamış atıl kalmıştır ve bu sebepten halk bu lambaları çoğu zaman başka amaçla kullanmışlardır.

Sokak lambalarının çalışmaması en çok eleştirilen konulardan biridir. Latife, sokak lambalarının aydınlatmasında yaşanan sorunları alaycı bir dille aktarmıştır; "İstanbul sokaklarında yakılacak gaz lambaları bundan üç ay önce seyahate çıkmış olduklarından yakında görev yerlerine dönecekleri işitilmiş ise de biz buna asla inanamayı" (Latife, 19 Ağustos 1874, s. 1). İstanbul sokak lambalarının üç ay gibi uzun bir zamandır yanmaması haberde yer almıştır. Bu tür haberlerin çokluğu dikkat çekmektedir.

\section{İstanbul'da Ekonomik Hayat}

Günümüzde olduğu gibi ekonomi, basın yayın organlarının bir numaralı haber ve eleştiri kaynağı olmuştur. Başka bir ifadeyle insanların geçim kaynakları ve yaşam şartları her zaman en önemli konuların başında gelmiştir. Özellikle 19. yüzyıl Osmanlı'sının ekonomik şartları göz önüne getirildiği vakit dönemin basını ister istemez ekonomik meselelere eğilme ihtiyacı duymuştur. $\mathrm{Bu}$ açıdan Latife gazetesi de çağdaşları gibi ekonomi haberlerine mizahi bir dille yer vermiştir. Mesela; "İstanbul'da bulanan dilenciler bir yere toplanıp kendi halleri ile bazı esnafin hallerini mukayese ederek kendi hallerini esnafin halinden daha refah ve rahat içinde olduğuna karar vermişlerdir" (Latife, 5 Mayıs 1875, s. 56). Haberde esnafin durumu dilencilerle kıyaslanarak dilencilerin durumunu daha iyi olduğu esnafin kan ağladığı anlatılarak bu durum eleştirilmiştir.

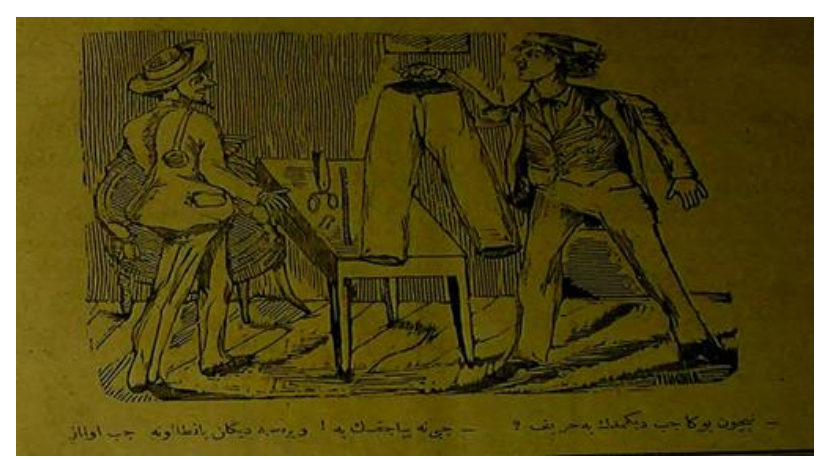

Resim 3. Ekonomik Hayatın Tasvir Edildiği Karikatür 
Ekonomik hayatta yaşanan sıkıntılar karikatürlere de konu olmuştur. Müşteri ile terzi arasında geçen konuşmada ekonomik sıkıntılar ve pahalılık dile getirilmiştir. Karikatür altı diyalog şu şekildedir; Müşteri terziye çıkışarak:

"-Niçin buna buna cep dikmedin be herif?

-Cebini ne yapacaksın be! Veresiye dikilen pantolona cep olmaz” (Latife, 5 Eylül 1874, s. 4). Pahalılık nedeniyle alım gücünün düşmesi ince bir hicivle karikatüre konu olmuştur.

\section{İstanbul Yeni Cami Çevresi Sosyal Hayat}

Osmanlı klasik döneminin önemli mimari eserlerinden biri olan İstanbul Yeni Cami, Eminönü semtinde yer almaktadır. Caminin inşasıyla beraber çevre muhitinde canlılık yaşanmıştır. Bunların en başında çevresine açılan dükkanlar ve bu sayede zamanla artan ticaret gelmektedir. Yeni Cami'nin bu özel konumu gereği burada yaşananlar Latife'nin de üzerinde durduğu hususlardan birisi olmuştur. Bu haberlere örnek verecek olursak; "Yoluna mecburi rahat ve doğru gitmemek murad eden var ise Balık Pazarı Kapısı yolundan ve arkadaşının sözünü işitmemek isteyen olur ise Yeni Câmi civarından gidip gelmelidir" (Latife, 27 Ekim 1874, s. 3). Balık Pazarı taraflarının çok kalabalık olduğu için insanların rahat hareket edemediği, Yeni Cami tarafında ise satıcıların seslerinden bir şey duymanın zor olduğu dile getirilerek bu durum eleştirilmiştir. Anlaşılan esnaf malını satabilmek için bağırıp müşsteri çekmek istemektedir. Bu durum ise orada bulunan diğer kişileri rahatsız etmektedir. Kalabalık ve gürültünün fazlalığı gazeteye eleştiri malzemesi olmuştur.

\section{Posta Teşkilatı}

Latife'nin eleştirdiği konulardan bir diğeri de İstanbul Posta Teşkilatı'nın eksiklikleridir. Bu bağlamda bir örnek vererecek olursak; "Postaya verilen mektupların vaktiyle mahalline ulaştırılmamasından dolayı şikâyet üzerine bundan sonra posta dağıtıcılarından bir haftadan fazla yanında mektup alıkoyanlar olur ise şiddetle cezalandırılacakları haber alınmıştır" (Latife, 12 Ağustos 1874, s. 2). Anlaşıldığı üzere postacıların mektupları sahiplerine ulaştırması uzun süre almaktadır. Bu durum büyük bir sorun haline gelmiş̧ir. Gazetenin eleştirileri idareciler tarafindan haklı görülüp görülmediği gerekenin yapılıp yapılmadığı hakkında bir bilgi gazetede yer almamıştır.

\section{İstanbul'da Ulaşım}

Latife gazetesinin üzerinde durduğu önemli başl1klardan bir diğeri ise ulaşımda yaşanan sorunlar olmuştur. İstanbul nüfusunun artmasıyla yaşanan sıkıntılar ve ulaşımdaki sorunlar gazetenin en önemli eleştiri konularından birini teşkil etmiştir. Nüfusun artmasıyla birlikte iç kesimlerden boğaza doğru yerleşim artmış ve bir kıyıdan diğer kıyıya gidiş geliş zorunlu hale gelmiştir. İlk önceleri kayıklarla sağlanan ulaşım tehlikeli ve zor olması nedeniyle zamanla yerini daha büyük ulaşım araçları olan vapurlara bırakmıştır. Şirket-i Hayriye vapurlarında yaşanan kalabalık ve ulaşımdaki rahatsızlıklar eleştiri konusu edilmiştir. Kara ulaşımında ise tramvaylar en önemli unsurdur. Önceleri atlı tramvay kullanılırken zamanla elektrikli tramvay kullanılmıştır. Ayrıca halk bir türlü bu yeni ulaşım araçlarına alışamamıştır. Çünkü gazetede birçok kez tramvayların karıştığı kaza haberi yer almıştır. Anlaşılan vatandaş tramvaylara ve onlar için ayrılan yollara tam olarak alışamadığı için pek çok kez kazalar yaşanmış Latife de bu sorunu gazetede kendisine çokça eleştiri malzemesi yapmıştır.

\section{Tramvay Şirketi}

20. yüzyılın başlarında, sanayileşme ve buna bağlı olarak şehir merkezlerindeki nüfus artışlarıyla birlikte kentler büyümüş bu ise beraberinde konut-işyeri arasında yolculuk talebini doğurmuştur. Bu talebin giderilmesi için süreç içinde teknolojik gelişmelere bağl1 çözümler devreye girmiştir. Bu bağlamda İstanbul'da ilk tramvay, Azapkapı-Beşiktaş arasında 1871 tarihinde çalışmaya başlamıştır. Halk, bu yeni ulaşım aracını çok sevmiş fakat tramvay arabaları ihtiyacı karşılayamamış ve vagonlarda yer bulmak mümkün olmamıştır. Ayrıca caddeleri dolduran halk sebebiyle tramvaya yol bulmakta zor olmuştur. 
Latife'de yer alan Tramvay Şirketi ile ilgili haber şu şekildedir; "Tramvay Şirketi kendine mahsus olan yolun etrafina demir parmaklık çekmek düşüncesinde imiş. Bu tedbir ile hem bayraktarlara (Osmanlı' da tramvaylara bayrakla yol gösteren, bayrak tutan kişiye verilen addır.) aylık vermekten kurtulacağ 1 ve hem de bundan böyle hiçbir kaza olmayacağı açıktır" (Latife, 13 Ekim 1874, s. 1). İstanbul halkı yeni olan bu ulaşım aracına uzun süre alışamamıştır. Bu nedenle tramvay yolunda pek çok kaza yaşanmıştır. Ayrıca tramvayları çekmesi için zor şartlarda çalıştırılan atlar, kalabalık ve rahat olmayan toplu ulaşım araçları, tramvay bayraktarlarında yaşanan sıkıntılar gibi pek çok sorun Latife'ye eleştiri malzemesi olmuştur.

\section{Şirket-i Hayriye}

Sultan Abdülmecid tarafından 1854 yılında kurulan Şirket-i Hayriye isimli vapur işletme şirketinin faaliyete geçmesiyle beraber İstanbullular rahat bir şekilde İstanbul'un iki yakasına ulaşma imkânına sahip olmuşlardır. Özellikle İstanbul'da nüfusun artması ve boğazda yeni yerleşim yerlerinin kurulması vapurları zaruri bir hale sokmuştur. Böylece Şirket-i Hayriye kurulmuş olup vapur sayısı ve yolcu taşıma kapasitesi zamanla artmıştır. Ancak zaman içerisinde diğer kurumlarda yaşanan aksaklıklar gibi Şirket-i Hayriye'de bazı sorunlar meydana gelmeye başlamıştır.

On altıncı sayıda yer alan haber şu şekildedir; "Şirket-i Hayriye idâresi tarafından vapur kamaralarında yatılması önceden yasaklanmış ise de bu defa Ramazan münâsebetiyle yatmak isteyenlerin uzunluğu memurlar tarafindan ölçülüp kaç insan enine eşit gelir ise o kadar yer paras1 alınarak yatmalarına izin verilmiştir" (Latife, 16 Ekim 1874, s. 1). Vapurlarda vatandaşların oturma yerlerini farklı amaçla kullanması oturma yerlerine yatmaları haber konusu olmuştur. Anlaşılan vapurlardaki kullanım alanları ve kamaraların amaçları dışında kullanılmıştır. Ayrıca kullanılan oturak malzemelerin rahatsız oluşu da Latife' de yer alan başka haberlerde sıkça aktarılmıştır. Şirketin bu gibi sorunları çözmesi gerektiği haberde dile getirilmiştir.

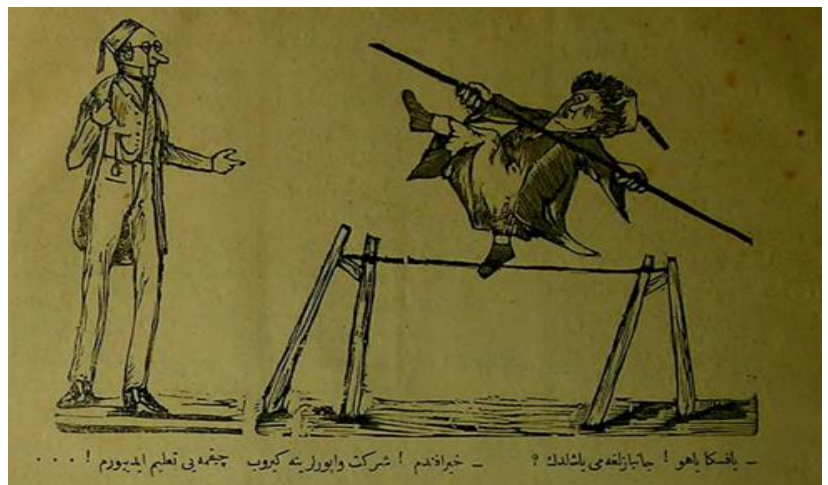

Resim 4. Şirket-i Hayriye'de Yaşanan Sıkıntıların Tavsir Edildiği Karikatür

Şirket-i Hayriye'de yaşanan en büyük sıkıntı ise vapurların kalabalık olmasıdır. Bu konuyu anlatan birden fazla karikatüre ve birçok habere Latife'de rastlanmaktadır. Bu durum sorunun büyüklügünü ve önemini göstermektedir. Bu konu ile ilgili karikatür Latife'nin üçünçü sayısında şu şekilde yer almıştır; Karikatürde vapurdaki kalabalık sonucu vapura binebilmek ve vapurdan inebilmek için vatandaşın verdiği uğraş alaycı bir dil ile aktarılmıştır. Karikatür altı diyalog şu şekildedir;

“-Baksana yâhu! Cambazlığa mı başladın? 4).

-Hayır efendim! Şirket vapurlarına girip çıkmayı öğreniyorum!” (Latife, 19 Ağustos 1874, s.

\section{Omnibüs Arabaları}

Osmanlı Devleti'nde kullanılan bir diğer toplu taşıma aracı omnibüs arabalarıdır. 1870 yılında kullanılmaya başlanan bu araçlar Azapköy-Beşiktaş arasında faaliyet göstermiştir. Ancak başlangıçta 
bu toplu taşıma araçları İstanbul gibi büyük bir şehre yeterli gelmemiştir. Bu nedenle yaşanan olumsuzluklar da Latife'nin gündem maddeleri arasında yerini almıştır. Gazetede yer alan bir telgrafta omnibüs arabalarının yoldan kaldırdığı toz eleştiri konusu olmuştur. Gazeteye gelen telgraf şu şekildedir; "Beyoğlu Doğruyol: Tozlar arasındaki muharebe henüz son bulmadı. Bu muharebeye omnibüs arabalarının sebep olduğu zannedilmektedir" (Latife, 26 Ağustos 1874, s. 4). İfadeleriyle mizahi bir dille yaşananlar telgraf vasıtasıyla anlatılmıştır. Anlaşılacağı üzere omnibüs arabaları ya da tramvaylardan kalkan toz çok fazla eleştiri konusu olmaktadır. Dönemin şartları gereği yollar çok bozuktur. Toprak yolda atlar toz kaldırmaktadır. Yağmur yağdığında ise insanlar çamurdan yürüyememektedir. Bu sorunlar gazetede pek çok kez haber ve eleştiri konusu olmuştur.

\section{Latife'nin Diğer Gazetelerle İlişkisi ve Pul Vergisi}

Latife'nin belki de en çok üzerinde durduğu husus dönemin diğer gazeteleri hakkında (Mecmua-i Maarif, Basiret, Hayal, Şark, Ceride-i Havadis, Tiyatro, Hulasatü'l-Efkar, Terakki, Telgraf, Medeniyet, Ruzname, Letaif-i Asar, Sadakat, Kamer, Kahkaha v.b.) yazılan haberlerden oluşmaktadır. Bu yazılar çoğunlukla eleştirel bir vaziyettedir.

Gazetenin ilk sayısında yer alan bir ilanda Latife kendi reklamını yapmışır ve dönemin diğer gazetelerine birer cümle ile atıfta bulunmuştur; "Harâç mezât. Ey canım isteklisi kalmasın alan pişman almayan mutlu. Basiret'in bitmez tükenmez ihtarları, Şark'ın anlaşılmaz karışıklıkları, Ceride'nin eczane ilanları, Mecmua'nın bayat beyitleri, Hayâl'in saçma hayalleri, Tiyatro'nun dırdırları, elhasıl bütün gazetelerin yalan-dolan sayfaları, Latîfe'nin alayları, bedavadan dörtte bir eksiğine satılıktır" (Latife, 12 Ağustos 1874, s. 2). Latife ilk sayısında dönemin gazetelerini eleştiri konusu edilmiştir. Latife, Basiret için sürekli uyaran, Şark için anlaşılmaz, Ceride için eczacı, Mecmua için bayat beyitler yazan, Hayal için hayalci, Tiyatro için dırdırcı gibi ithamlarda bulunmuştur. Bu tenkitler dönem gazetelerine Latife'nin bakış açısını da ortaya koymaktadır.

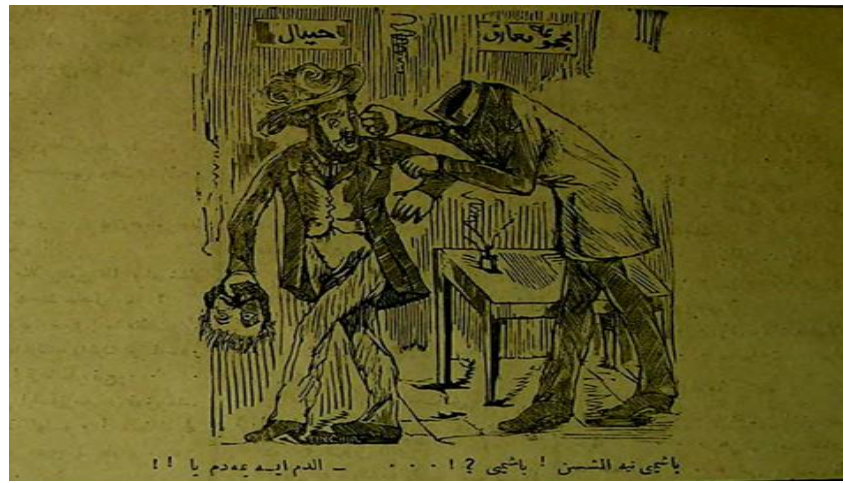

Resim 5. Mecmua-i Maarif ve Hayal Gazeteleri Arasındaki Çekişmelerinin Tavsir Edildiği Karikatür

Dönem gazeteleri arasında yaşanan çekişmeler karikatürlerede konu olmuştur. Mecmua-i Maarif ve Hayal Gazeteleri arasında yaşanan çekişmeyi anlatan karikatür Latife'nin beşinci sayısında yayınlanmıştır. Mecmua-i Maarif ve Hayal adlı gazeteler birer insan şeklinde resmedilmiş. Hayal'in elinde Mecmua-i Maarif' in kesilmiş başı vardır ve aralarında şöyle bir diyalog geçmektedir;

"Mecmua-i Maârif: -Başımı niye almışsın başımı?!

Hayâl: -Aldım ise yemedim ya" (Latife, 26 Ağustos 1874, s. 4). 


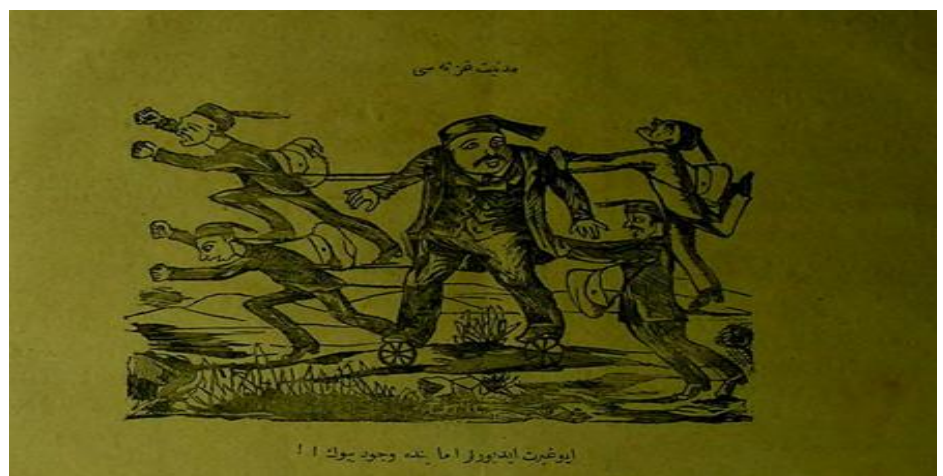

Resim 6. Medeniyet Gazetesi İle Diğer Dönem Gazeteleri Arasındaki Çekişmelerinin Tavsir Edildiği Karikatür

Latife'de on ikinci sayıda yer alan başka bir karikatürde dönemin gazeteleri arasında yaşanan çekişme ve çatışma güzel bir şekilde tasvir ediliyor. Medeniyet Gazetesi'nin bir yandan çekiştiren bir yandan iten gazete dağıtıcıları gösteren karikatür altı diyalogda; Medeniyet Gazetesi olarak çizilen cüsseli bir adam kendisini çekiştiren c1lız kimseleri kastederek;

“-İyi gayret ediyorlar ammâ bende vücut büyük!!” (Latife, 2 Ekim 1874, s. 4). Anlaşılacağı üzere dönem gazeteleri arası rekabet ve çekişme çok büyüktür. Kullanılan dil ve ithamlar bu çekişmenin büyüklüğünü gözler önüne sermektedir. Özellikle Mecmua-i Maarif ve Hayal gazeteleri arasındaki kesik baş tasvirinin yer aldığı karikatür bu çekişmeye önemli bir göstergedir.

\section{Pul Vergisi}

Latife gazetesinin üzerinde durduğu diğer husus ise pul vergisidir. 1875 y1lında yürürlüğe giren bu sistem yani Damga Nizamnamesi, Osmanlı basınına ağır bir ekonomik yük getirmiştir. $\mathrm{Bu}$ vergiye pul vergisi de denilmektedir. Latife Gazetesi'nin 1875 yılında çıkan sayılarında gazeteye yapıştırılan bu pulları görmek mümkündür.

Pul vergisinin konu edildiği haber şu şekildedir; "Gazete kağıtları bir yere toplanarak şimdiye kadar kendi üzerlerine basılan kara yazılara kanaat etmeyip bir de pul yapıştırdıkları için makinecileri şikâyet etmeye karar verdikleri söylenmektedir" (Latife, 7 Mayıs 1875, s. 57). İfadeleriyle pul vergisi eleştirilmiştir. Alaycı bir dille gazete kâğıtlarının ağzından kişileştirme yapılarak kendilerine pul yapıştırılmasını şikâyet etmektedirler.

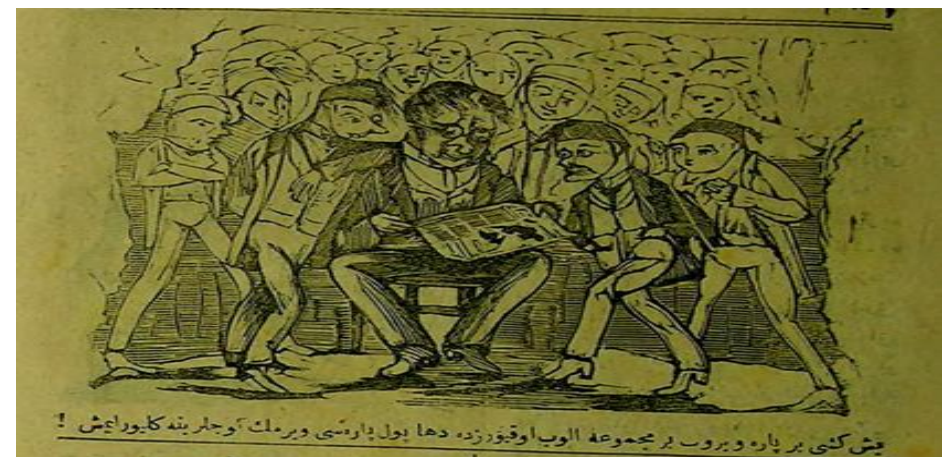

Resim 7. Pul Vergisinin Getirdiği Sıkıntıların Tavsir Edildiği Karikatür

Latife'de yer alan karikatürde ise pul vergisi yine eleştiri konusu olmuştur. Birçok kişinin bir arada gazete okuduğu karikatür Latife'de yer almıştır. Karikatür altı diyalog şu şekildedir;

"-Beş kişi bir para verip bir mecmua alıp okuyoruz da daha pul parası verme güçlerine gidiyormuş!” (Latife, 7 Mayıs 1875, s. 64). İfadeleriyle pul vergisinin dönemin gazetelerine çok ağır ekonomik yük bindirmesi eleştiri konusu olmuştur. Karikatürde gazete ücretlerinin artmasıyla tek 
gazeteyi beş kişinin okuması ve gazete satışlarının düşmesiyle vergi yükünün altında ezilen gazetelerin ne yapacağ 1 eleştirilmiştir. Bu ekonomik yük beraberinde dönemin gazetelerinin personel ve yazar giderlerini kısarak pul vergisinin getirdiği ekonomik baskıdan kurtulmaya zorlamıştır. Hatta pek çok gazete satış fiyatlarına zam yaparak bu sorunu aşmaya çalışmış ya da daha fazla dayanamayıp kapanmak zorunda kalmıştır.

\section{Latife'de Osmanlı Tiyatrosu ve Moda Haberleri}

Latife'de yer alan bir başka konu ise dönemin Osmanlı tiyatrosu hakkında Latife gazetesinde oldukça fazla yer bulan haberlerdir. Bu bağlamda Gedikpaşa Tiyatrosu sahibi Güllü Agop Efendi ve Dikran Çuhacıyan, Osmanlı Tiyatrosu ve Karagöz oyunu eksenli hiciv yazıları ve tiyatro yorumları dikkat çekmektedir. 1870'li yıllar, Osmanlı eğlence kültüründe tiyatronun kendisine kalıcı yer edinmeye başladığı yıllardır. Sözü edilen Agop Efendi, Güllü Agop adıyla meşhur, Müslümanlığı seçip Güllü Yakup adını alan Osmanlı'nın Ermeni tebasından Agop Vartovyan'dır. Gedikpaşa Tiyatrosu ile birlikte İstanbul'da 10 yıl müddetle Türkçe oyun oynama imtiyazını almıştır. Anadolu ve Avrupa yakalarında tiyatro salonları da kurmuştur. Güllü Agop için modern tiyatronun kurucusu da denilmektedir.

Latife'de daha çok Gedikpaşa Tiyatrosu'nun fiziki şartlarıyla ilgili haber yayınlanmıştır. Tiyatroda yaşanan sıkıntılardan bazıları şu şekilde dile getirilmiştir; "Yaz mevsiminin yaklaşması münasebetiyle Üsküdar'da Bağlarbaşı'ndaki Agop Efendi'nin Tiyatrosuna "sırf müşterilerin havasızlıktan hasta olmaması için" dört adet hava makinesinin Avrupa'ya sipariş olunduğu haber alınmıştır" (Latife, 13 Nisan 1875, s. 17). Tiyatro için getirilecek makineler Latife'ye bu sözlerle konu olmuştur. Bu haberden anlaşılacağı üzere Gedikpaşa Tiyatrosu'nun fiziki şartları pekiyi değildir. Binanın çok eski olması ve havalandırma sıkıntı yaşanması eleştirilmiştir. Anlaşılacağı üzere; Gedikpaşa Tiyatrosu'nun işleri çok iyi olmalı ki kalabalık yüzünden insanlar havasız kalmakta ve rahatsız olmaktadır. Hatta bu sorun için Avrupa'dan makineler getirileceği de haberde anlatılmıştır.

Ayrıca Latife'de Güllü Agop Efendi ve Dikran Çuhacıyan (Ermeni asıllı Türk sahne müziği bestecisidir. Dikran Çuhacıyan aynı zamanda Osmanlı Devleti' nde, ilk operet bestecisi kimliği yanında, ilk operet tiyatrosunu kuran isimdir.) arasında yaşanan birleşme planları ile ilgili haberlerde çokça yer almaktatır. Gedikpaşa Tiyatrosu sahibi Güllü Agop Efendi ve Dikran Çuhacıyan Opera Tiyatrosu'nun arasında yaşanan birleşme konusu haber edilmiş̧ir. "Bundan önceki sayılarımızın birisinde her ne kadar Güllü Agop tiyatrosu ile Çuhaciyan Dikran opera tiyatrosu'nun birbirleriyle evlenmek fikrinde bulunduklarını yazmış isek de sonradan alınan haberlere göre birisinin yaşı pek büyük ve diğerinin pek küçük olduğu için bu husustan vazgeçmişlerdir" (Latife, 13 Mayıs 1875, s. 69). Anlaşılacağı üzere Gedikpaşa Tiyatrosu sahibi Güllü Agop Efendi ve Dikran Çuhacıyan Opera Tiyatrosu'nun birleşme planları vardır. $\mathrm{Bu}$ mesele daha sonraki yıllarda tatlıya bağlanarak gerçekleşmiştir.

\section{Moda Haberleri}

Latife gazetesinde dikkat çeken konu başlıklarından biri de "Beyoğlu Matmazelleri" başlığı ile yer alan moda haberleri ve konusu olmuştur. Bu eksende toplumun yaşamını giderek daha çok etkileyen Beyoğlu kadınlarına yönelik yaşam tarzı konu edilmiş̧ir. Avrupa modeli giysinin yanı sıra, Avrupa örnekli sosyal yaşam da konu yapılmıştır. Latife ise "Beyoğlu Matmazelleri" başlıklı yazı ile moda konusununda İstanbul'da yaşanan gelişmeleri çeşitli şekillerde eleştirmiştir.

Latife'nin yedinci sayısında yer alan haberde Beyoğlu matmazelleri ile ilgili haber şu şekildedir; "Bundan önce toplanacaklarını yazmış olduğumuz şıklar meclisinde bu senenin modası için kış ve yaz ağır palto ve cebi hafif pantolon giyilmeye ekseriyet ile karar verilip üyelerin beğeni sesleri ayyuka çıkmıştır" (Latife, 17 Nisan 1875, s. 27). Matmazellerin senenin modası hakkında aldıkları karar dile getirilmiştir. Kış ve yaz ağır palto ve cebi hafif pantolon giyileceği ifade edilmiştir. Anlaşılacağı üzere burada Latife kıyafetlerin hep aynı olduğunu ancak harcanan para ile cebin hafiflediğini alaycı bir dille anlatmak istemiştir. Latife burada daha çok Avrupa giyim tarzını 
eleştirilirken bu durumun Osmanlı toplumu tarafından bir özenti halini alması Latife'nin eleştirdiği noktadir.

\section{Sonuç}

Basın yayın organları oluşturduğu kamuoyu ve etkileriyle tarihte olduğu gibi günümüzde de halk1 etkileyen en etkili güçlerden biridir. Bu güce sahip olmak isteyen hem iktidar hem de muhalefet basın yayın organlarına kontrolü altına almaya çalışmıştır. Bu yüzdendir ki basının etkisi tartışılmaz bir konumdadır. Bu güce görsel unsur ve keskin bir yorum ile alaycı bir bakışta eklenince etki daha da artmıştır. Bunu sağlayanda mizah basını olmuştur. Mizah basınının insanları eğlendiren tarafının olması onun etki alanını daha da genişletmiştir. Bu sayede insanlar hem eğlenirken hem de ülke gündemi hakkında çoğu zaman keskin ifade ve yorumları okumuştur. Bu ilgi beraberinde mizah basınının tepki görmesinede neden olmuştur.

Latife gazetesi 1874-1875 yılları arasında Zakarya Beykozluyan tarafindan yayınlanmıştır. Bu nedenle de bu yıllar arasında yaşanan olaylar onun ilgi alanına girmiş ve çoğu kez eleştirisinden kurtulamamıştır. Özellikle dönemin gazeteleri, İstanbul Belediyesine ait işler ve sosyal-ekonomik sorunlar onun gündeminden hiç düşmemiştir. Bu eleştiriler sayesinde İstanbul'daki sosyal hayat ve yaşayış hakkında kayda değer bilgilere ulaşmak mümkündür. İstanbul belediye haberlerinde sokakların temizliği, yollardaki çamur-toz ile alt yapı yetersizliği ve artan nüfusa işaret edilmiştir. Kalabalık tramvaylar ile yolların dar olmasıyla pek çok kaza yaşanmıştır. Bu durum Osmanlı halkının henüz tramvayları benimseyemediğinin bir kanıtı olarak gösterilmiştir. Vapurların yavaşlığı ve kalabalık olması da dönemin sıkıntıları arasında yer almıştır. Büyük zahmetlerle kurulan sokak lambaları yanmamış ve lambalar başka amaçlar için kullanılmışıı. Esnafların bozuk mal satması, kalabalık ve gürültü alışveriş yapılan yerlerdeki en büyük sıkıntı olmuştur. Yeni Cami ticari hayatı canlı olmakla birlikte esnaf ekonomik şartlar gereği zorlanmıştır. Bütün bunlar Latife'nin gündem maddelerini oluşturmuştur.

Sosyal hayatta ise pahalılık ve geçim sıkıntısı sorunları yaşanmıştır. Tekel idaresi bozuk ve kalitesiz tütün üretmiştir. Terkos Gölü'nden elde edilen su ile İstanbul halkına yeterli ve temiz su sağlanamamıştır. Posta teşkilatındaki dağıtıcılar postaları sürekli gecikmiştir. Ayrıca tramvay, vapur, omnibüs arabaları gibi toplu ulaşım konularındaki aksaklıkları Latife sert bir dille eleştirmiştir.

Gedikpaşa Tiyatrosu'nun sahibi ve yöneticisi Güllü Agop ile Osmanlı Tiyatrosu atılım yaparak tiyatroya olan rağbet artmıştır. Buna rağmen Gedikpaşa Tiyatrosu fiziki açıdan çok yetersiz kalmıştır. Ayrıca geleneksel orta oyunu yerine Batılı ve çeviri oyunlar sergilenmiş halk bu durumu yadırgamıştır. Ayrıca toplumun yaşamını giderek daha çok etkileyen Avrupa tarzı giyimin yanı sıra, Avrupa örnekli sosyal yaşam da konu yapılmıştır. Batı özentisi olan bu durum eleştirmiştir.

Dönemin diğer gazeteleri ile arasında yaşanan çekişmeler büyük önem arz etmiştir. Bu çekişmeler kimi zaman abone bulup satış arttırma kimi zamanda taraf oldukları kesimlerin lehinde haber yapma şeklinde yaşanmıştır. Bu durumlar dönem gazetelerinin birbirlerini değersizleştirme politikası gütmelerine sebep olmuştur.

Latife 1874-1875 yılları arasında özellikle İstanbul'da halkın yaşadığ 1 pekçok sorunu gözler önüne sermiştir. İğneleyici bir dil kullanılarak yaşanan sıkıntılar ve dönemin gündemi Latife'ye konu olmuştur. Latife'den elde edilen bilgiler ile mizahi bir çerçeveden dönemin sorunlarına bakılarak sorunlara 1şık tutulmuştur. Latife gazetesinde siyasi olaylara çok az yer verilmiştir. Latife'de genellikle İstanbul gündemi ve yaşanan ekonomik sosyal sıkıntılar dile getirilmiştir. Osmanlı toplumsal yapısı ile illgili kayda değer verilere ulaşmak bu şekilde mümkün olmuştur.

\section{Yazarların Katkı Oranı}

Çalışma tek yazarlı olduğu için yazarın katkı oranı \%100'dür. 


\section{Çıkar Çatışması}

$\mathrm{Bu}$ çalışmada çıkar çatışması oluşturacak bir husus yoktur.

Açıklama: Bu çalışma 2019 yılında Kırşehir Ahi Evran Üniversitesi Sosyal Bilimler Enstitüsüne sunulan "Osmanlı Mizah Basınının Bir Temsilcisi: Latife Gazetesi (1874-1875)" isimli tezden faydalanılarak hazırlanmıştır.

\section{Kaynaklar}

Akyüz, K. (2017). Modern Türk edebiyatının ana çizgileri. İstanbul: İnkılap Yayınları.

Altın, H. (2014). II. Meşrutiyet devri Osmanlı mizah basını. Ankara: Grafiker Yayınları.

Apaydın, M. (2007). Tanzimat'tan sonra mizah ve hiciv, Türk edebiyatı tarihi. C.3, İstanbul: Kültür ve Turizm Bakanlığı Yayınları.

Baykal, H. (1990). Türk basın tarihi: 1831 - 1923. İstanbul: Afa Matbaacılık.

Beykozluyan, Z. (1874, 15 Ağustos). Havâdis-i dâhiliye. Latife, s. 2.

Beykozluyan, Z. (1874, 12 Ağustos). Muhavere. Latife, s. 2.

Beykozluyan, Z. (1874, 12 Ağustos). Telgraf. Latife, s. 3.

Beykozluyan, Z. (1874, 9 Ekim). İlânât. Latife, s. 4.

Beykozluyan, Z. (1874, 22 Ağustos). İlânât. Latife, s. 4.

Beykozluyan, Z. (1874, 5 Eylül). İlânât. Latife, s. 4.

Beykozluyan, Z. (1874, 26 Ağustos). Varaka. Latife, s. 2.

Beykozluyan, Z. (1875, 3 Nisan). Elenko hikâyesi. Latife, s. 3.

Beykozluyan, Z. (1875, 6 Nisan). Karikatür. Latife, s. 7.

Beykozluyan, Z. (1874, 24 Ekim). Ahvâl-i milel. Latife, s. 1.

Beykozluyan, Z. (1874, 29 Ağustos). Karikatür. Latife, s. 4.

Beykozluyan, Z. (1874, 19 Ağustos). Havâdis-i dâhiliye. Latife, s. 1.

Beykozluyan, Z. (1874, 27 Ekim). Latife'ye mahsus telgraf. Latife, s. 1.

Beykozluyan, Z. (1875, 10 Nisan). Havâdis-i dâhiliye. Latife, s. 13.

Beykozluyan, Z. (1874, 19 Ağustos). Havâdis-i dâhiliye. Latife, s. 1.

Beykozluyan, Z. (1875, 5 Mayıs). Havâdis-i dâhiliye. Latife, s. 56.

Beykozluyan, Z. (1874, 5 Eylül). Karikatür. Latife, s. 4.

Beykozluyan, Z. (1874, 27 Ekim). Havâdis-i dâhiliye. Latife, s. 3. 
Beykozluyan, Z. (1874, 12 Ağustos). Havâdis-i dâhiliye. Latife, s. 2.

Beykozluyan, Z. (1874, 13 Ekim). Havâdis-i dâhiliye. Latife, s. 1.

Beykozluyan, Z. (1874, 16 Ekim). Havâdis-i dâhiliye. Latife, s. 1.

Beykozluyan, Z. (1874, 19 Ağustos). Karikatür. Latife, s. 4.

Beykozluyan, Z. (1874, 26 Ağustos). Telgraf. Latife, s. 4.

Beykozluyan, Z. (1874, 12 Ağustos). İlânât. Latife, s. 2.

Beykozluyan, Z. (1874, 26 Ağustos). Karikatür. Latife, s. 4.

Beykozluyan, Z. (1874, 2 Ekim). Karikatür. Latife, s. 4.

Beykozluyan, Z. (1875, 7 Mayıs). Havâdis-i dâhiliye. Latife, s. 57.

Beykozluyan, Z. (1875, 7 Mayıs). Karikatür. Latife, s. 64.

Beykozluyan, Z. (1875, 13 Nisan). Havâdis-i dâhiliye. Latife, s. 17.

Beykozluyan, Z. (1875, 13 Mayıs). Havâdis-i dâhiliye. Latife, s. 69.

Beykozluyan, Z. (1875, 17 Nisan). Havâdis-i dâhiliye. Latife, s. 27.

Çakır, H. (1997). Osmanlı'da gazete reklamcılı̆̆ı. Ankara: Elit Yayınları.

Çavdar, T. (2007). İz birakan gazete ve gazeteciler. Ankara: İmge Kitabevi.

Çeviker, T. (1986). Gelişim sürecinde Türk karikatürü-I Tanzimat ve İstibdat dönemi. İstanbul: Adam Yayınları.

Ertuğ, H. R. (1970). Basın ve yayın hareketleri tarihi. İstanbul: Yenilik Basımevi.

İnuğur, M. (1958). Basın ve yayın tarihi. İstanbul: Der Yayınları.

Kabacalı, A. (2000). Başlangıcından günümüze Türkiye'de matbaa basın ve yayın. İstanbul: Literatür Yayınları.

Lewis, B. (1993). Modern Türkiye’nin doğuşu. Ankara: TTK Basımevi.

Özer, A. (1994). Karikatür: İletişim çizgi dili. Eskişehir: Anadolu Üniversitesi İletişim Bilimleri Fakültesi Yayınları.

Topuz, H. (1997). Başlangıcından bugüne dünya karikatürü. İstanbul: İnk1lap Yayınevi. 


\section{Extended Abstract}

\section{Introduction}

The press is one of the most influential forces that affect the public today, as it has in the past with its public opinion and influence. Both the government and the opposition, who wanted to have this power, tried to take control of the media. This is why the effect of the press is indisputable. The effect increased even more when it was added to this power with a cynical look with a visual element and a sharp interpretation. This was provided by the humor press. The humor press has an amusing side, which has further expanded its scope. In this way, people often read sharp statements and comments about the country's agenda while having fun. This interest also caused the humor press to react.

Latife newspaper, which is one of the first humor newspapers, provides information about the history of daily life, as well as Istanbul news and municipal services, transportation and tramway in the Ottoman, ferry, omnibus problems, drama and western style in the Ottoman Empire. There were many news and articles about clothing, fashion. Since the news and articles in Latife are a humor newspaper, they generally have a critical approach to the events and make mock comments.

\section{Method}

The published issues of the Latife newspaper were accessed through the Hakk1 Tarık Us Library. The published numbers were transcribed from the Ottoman alphabet. Also, Turkish equivalents were used in Arabic and Persian words. The topics in Latife are sorted according to intensity and importance and gathered under certain headings. Thus, it was possible to look through the eyes of Latife between 1874 and 1875.

\section{Results}

As a result, Latife was exposed to many problems experienced by the people, especially in Istanbul between 1874 and 1875. In his newspaper, there are very few political events. Generally, the agenda of Istanbul and the economic social problems experienced were mentioned. It is understood that many economic and social problems experienced by the people in Istanbul between 1874 and 1875 , especially the difficulties in transportation, are experienced in similar ways today.

\section{Discussion and Conlusion}

The general aim of this study is to examine the published issues of the newspaper Latife, a humor newspaper published by Zakarya Beykozluyan published between 1874 and 1875. As it is a humor newspaper, it was aimed to better understand the period with the satire art it used. In addition, the most important feature of humor newspapers is cartoon art and visual content, which is considered very important to understand the period. Because, with the critical approach and cynical interpretation, visuality has been thought to have a great effect on people.

Considering the power of the media to direct the society, the effect of the humor press, which adds a critical approach and interpretation and visuality, has been indisputably great. The cartoons are important masters, both because they are visual and because of the intense meanings they contain. Every number of cartoons are included in the newspaper, and the agenda was conveyed to the reader with these cartoons.

Latife newspaper was published between 1874-1875. For this reason, the events that took place between these years were of his interest and he could not get rid of his criticism. Especially the newspapers of the period, the works of Istanbul Municipality and social-economic problems have never fallen from its agenda. Thanks to these criticisms, it is possible to reach remarkable information 
about social life and life in Istanbul. In Istanbul municipal news, the cleanliness of the streets, muddust and insufficient infrastructures on the roads and the increasing population were pointed out. Many accidents have occurred with crowded trams and narrow roads. This has been shown as evidence that the Ottoman people have not yet adopted the trams. Slowness and crowd of ferries were among the problems of the period. Street lamps, installed with great effort, were not burned and the lamps were used for other purposes. The fact that tradesmen sold bad goods was the biggest problem in crowded and noise shopping places. Although the commercial life of Yeni Mosque is alive, artisans have been forced due to economic conditions. All this has created the items of the agenda of Latife.

In social life, problems of cost and livelihood have been experienced. The monopoly administration produced bad and poor quality tobacco. With the water obtained from Terkos Lake, sufficient and clean water has not been provided to the people of Istanbul. Dispatchers in the postal agency are constantly delayed by the mail. In addition, Latife criticized the flaws in public transportation issues such as trams, ferries and omnibus cars.

With Güllü Agop, the owner and manager of Gedikpaşa Theater, the Ottoman Theater has made a leap, and the demand for theater has increased. Despite this, Gedikpaşa Theater was very inadequate in terms of physics. In addition, the Western and translation games were exhibited instead of the traditional middle game, and the public was fooled. In addition to European clothing, which affects the life of society more and more, European-style social life has also been the subject. This Western wannabe criticized this situation.

The conflicts between the other newspapers of the period were of great importance. These conflicts were sometimes found in the form of finding subscribers and increasing sales, and sometimes making news in favor of the parties to which they are parties. These situations caused period newspapers to pursue a policy of devaluating each other.

Latife between 1874 and 1875 revealed many problems experienced by the people especially in Istanbul. Problems experienced using a sarcastic language and the agenda of the period have been the subject of Latife. With the information obtained from Latife, the problems of the period were shed light from a humorous framework. There are very few political events in the newspaper Latife. In Latife, the agenda of Istanbul and the economic social problems experienced were generally mentioned. In this way, it was possible to reach significant data about the Ottoman social structure. 